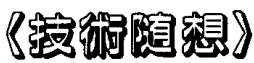

\section{職人芸と機械化 \\ Artisan Skill and Manufacturing Technology}

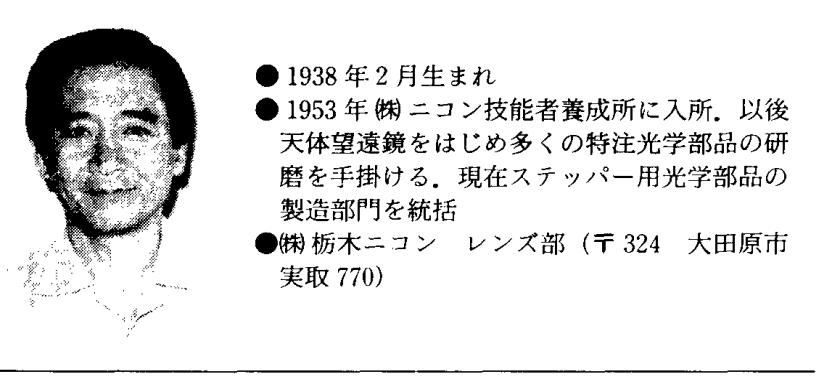

かつてレンズを磨くという職業は研磨機という 機械を使ってはいるものの，職人の手に委ねられ ており，そこには機械の母性原則は存在していな かった。昭和 40 年代に入り高速研磨機の導入が 始まり，レンズも機械部品と同じようにワンピー スで加工するようになると, 研磨機の性能がレン ズの加工結果に大きく影響するようになってき た.

コンパクトカメラやホームユースのビデオカメ ラ用レンズ等は, 現在では研削（あらずり）から コート工程, さらに組立までが, 加工機械とロボ ットあるいはオートローダーの組合せで自動化さ れ，まさに機械化の様相を呈している。それでも レンズ研磨の最大の特徴である面接触加工は, 治 工具類の準備作業という段階で, ある程度の熟練 者を必要としている。

光学素子の二ーズが多様化し, 測定技術が進ん できた現在, 通常求められる精度, 特に面精度 は, 理論的な基準面に対しての差異が $0.01 \mu \mathrm{m}$ 以 下である. 例えば直径 $100 \mathrm{~mm}$ の加工球面を東 京ドームの広さに換算すると, 髪の毛一本分の誤 差は許さないというレベルの要求精度である。こ れらの加工についても部品の形状, 材料の制約は あるものの, 職人の手を煩わすことなく連続的に 生産が可能になってきている。しかし, 研磨機械 が順調に生産を始めるまでの治工具の準備作業 は，相変わらず研磨の熟練者を中心とした技能者 集団によって行われているのが現状である.

レンズ研磨が, 前述のように, 刃具による鏡面 の創成ではなく，遊離砥粒を用いたピッチあるい は研磨シートによる面接触で行われる限り, 高精

Jour. JSME

\section{横山漛造}

Taizo YOKOYAMA

度な治工具を作るためには研磨熟練者の手を必要 とする.

私がレンズ研磨の世界に足を踏みいれて 40 年 が経つ. 職人の集団の中で, 息を凝らして高精度 のレンズを磨き始めた頃, 職場で気になることが あった．時々先輩達が黒いガムを鲾んでいる．仕 事中に無節操な, と思ったが実はガムではなく研 磨に使うピッチを嚙んでいるのである，空調設備 などない中での研磨加工は過酷である。体温は個 人的には病気でもしていない限り一定である。ピ ッチを口の中で体温に馴染ませ䨑応えで堅さを調 べていたのである. 悪い環境の中でも職人は知恵 を絞って情報の収集に努力したのである. 当時に 比べると, 今は作業環境は整備され, 副資材も進 歩した。職人達が体で覚えた情報収集の知恵の多 くは不用となってしまった。

以後測定技術は着実に進歩を遂げてきたが, 加 工に関しては昭和 40 年代まで技術者の介入を許 さない職人の独壇場であった。それは職人の技と 測定技術との戦いの様相を呈していた.

40 年代半ばになると国内はもとより, 国際的 にも競争力を高めるため, 製品の差別化と価格面 での差別化が必要となり, 使われる光学素子に対 しても超高精度が要求されると同時にコスト面で の制約が厳しくなってきた。一方で職人が次々と 退役し，その補充がどの分野でも思うに任せない 状況が発生し始め, レンズ研磨の超精密機械加工 への取組みの引き金となったのである.

当社においても超精密機械加工への取組みが技 術部門の手によって積極的に行われ, 現在にいた っている，机上で計画されたものが狙いどおりの

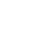


結果となるものもあれば惨澹たる結果に終わるも のもある。ここで注目しなければならないのは， 職人を参画させた計画のほうが成功の確率が高い ということである。技能者は機械化に強い関心を 持ち，積極的に情報を提供する．技術者は技能者 の持つノウハウをいかに数值化出来るか努力す る.技能者のノウハウを, 数值化したパラメー夕 一に上手く組込むことができるかが成否の鍵とな る.

近年どこの企業でも，そしてどの製造分野にお いても職人の範疇に入る技能者が不足している. これは高学歷化と, 若い人達の製造業離れが主因 であるが，もう一つの側面としてさまざまな原因 はあるのだろうが，企業そのものが製造の場の近 代化を進める上で, 技術者主導で進めてきた経緯 にもよる。

幸い我が社の技能訓練の歴史は古く, 多くの優 秀な技能者を育ててきたが，それとても万全とは 言い難い。特にレンズ研磨の技能者が職人として のレベルに到達するには，長い期間を必要とする ので深刻な問題である。

私がレンズ研磨を始めたときに先輩から繰り返 し言われたのは「『あたり』『なじみ』『すいつき』 を体で覚えるように，それが解らんやつはレンズ 研磨は出来ない」と言うことであった。さらに， 「技能の道はけわしくて長い道である。これを修 業と言う. 強固な意思の下に初志を貫き通さねば ならない。修業とは無我無心になることである。 そして摩訶不思議な人間能力の極致に達するの だ」とも言われた。私はその先輩に多大な影響を 受け続けて修業をした積もりであるが, その足元 にも及んでいない. 先輩は企業の中での職人像に 付いても「匠の世界に没頭して, 環境の変化に見 向きをしないものは取り残される，質の良い情報 に敏感になり，積極的に取り込み自らの能力を切 硡琢磨し，常に向上を目指すのが企業人としての 職人である」と示唆された。
レンズ研磨における超精密機械加工と職人の加 工との大きな違いは，職人は修得した技能，いわ ゆる複雑で膨大な基礎情報（パラメーター）を， 状況に応じて瞬時に組合せを行い適切な加工を行 うことができること．また狙いと結果の差異があ ればその是正についての対応も速やかである。そ れに『情熱』が加味されるところに『摩訶不思議 な人間能力の極致』と表現される結果を生み出 す.

一方超精密機械加工においては，パラメーター を極限まで整理し，シンプルな加工メカニズムに よって狙いどおりの加工結果を得ようとする。そ の結果, 刃具にまでは至らないが, 極小のスモー ルツールによって加工を行う機構になる．職人が 行う面接触加工を機械に置き換えることは非常に 難しいのである。

加工機の精度を計測精度の極限にまで向上させ ることは可能であるが，この過程においては職人 の力を借りなければならない．また超精密機械加 工と言えども，その適用には部品の形状，材料の 制約がある。それらを除外しての物作りは企業と して成り立たないので必然的に職人の手に委ねら れることになる。それもやがては機械化が可能に なるのであるが，人間の知恵は無限であるので， 新たな素材，さらに高いレベルの部品が要求され れば，職人の手を煩わすことになる。

その絡みが継続的になければその企業は脱落す るのである。従って，八イテク時代の職人の役割 は極めて重要なのである.

日本の製造業が，今まで職人の果たしてきた役 割を正しく認識し, 将来の製造システムでの職人 の位置付けを明確にしないと, 国際競争のなかで 後退を余儀なくされるであろう。優秀な技能者を 育成して，入魂した製品を市場に出すことで企業 の繁栄があり, 社会性が位置付けられ, 従業員の 人間性を豊かにするのである。

(原稿受付 1993 年 9 月 17 日) 